\title{
sciendo
}

CIVIL AND ENVIRONMENTAL ENGINEERING REPORTS

E-ISSN 2450-8594

CEER 2021; 31 (1): 0106-0117

DOI: $10.2478 /$ ceer-2021-0008

Original Research Article

\section{THE RECLAMATION OF A MUNICIPAL WASTE LANDFILL - GRUDZIĄDZ CASE STUDY}

\author{
Kamil Artur MAJEWSKI ${ }^{1}$ \\ Science and Technology Park of the University of Zielona Góra, Zielona Gora, Poland
}

\begin{abstract}
Municipal landfills are one of the most human-transformed areas of nature, and the process of designing and building a landfill is one of the most difficult strategic issues within human clusters, in particular due to the requirements that a landfill should meet, including the method of its establishment and closure. The main aim of the article is to present a case study of one, currently reclaimed landfill, located in Grudziądz - a district town in the Kujawsko-Pomorskie Province - at Rataja Street, which was closed down in 1997. The discussion of this case was, in turn, an answer to the question about one of the possible methods of landfill reclamation. The article is based on the results of the author's own research - both in terms of field work and archive searches. The discussion of this case served to illustrate how the reclamation was carried out, what technologies of biogas recovery were used and what the results of the checks were.
\end{abstract}

Keywords: landfill, reclamation, Grudziądz, biogas recovery

\section{INTRODUCTION}

Municipal landfills are some of nature's most transformed areas. In terms of construction, landfills are among the most technically challenging facilities, they are required to be as tight as possible and to ensure a minimum impact on the environment, e.g. by maintaining a protective zone of at least $300 \mathrm{~m}$ from the nearest residential area, in order to avoid a direct impact of the landfill on residents

\footnotetext{
${ }^{1}$ Corresponding author: e-mail: k.majewski@pnt.uz.zgora.pl, ORCID 0000-0002-12229940
} 
$[2,6]$. At the same time these are facilities with a very large area and capacity, as well as a lifetime of many years. The nature of the stored waste and its chemical composition is very diverse. The harmfulness of a landfill to the environment depends on many factors, in particular on the properties of the waste (physical, chemical, biological), the quality of the ground, the management of the environment adjacent to the landfill and its operation, as well as the method of reclamation and final management of the landfill site. The nuisance to the environment and difficulties in the operation of a landfill are largely determined by the properties of the selected location [2].

The existence of landfills is inextricably linked with human life and activity. Therefore, it is impossible to abandon them altogether, instead one should strive to eliminate the negative effects of their functioning. Thus, the purpose of landfilling is to bring the non-recyclable waste to a state posing no threat to human life and health or to the environment. It should be noted that the landfills currently under construction are built based on projects in which both the method of constructing the landfill in accordance with the applicable regulations, as well as the duration of its existence and the method of reclamation after completion of its operation are recorded.

The legal conditions for the design, construction and subsequent operation of landfills are included in the Act on Waste of 14 December 2012 (Journal of Laws 2013, item 21) as well as executive acts and European directives, such as:

- Regulation of the Minister of the Environment on Landfills of 30 April 2013, - Regulation of the Minister of Economy on the Types of Waste that May be Stored in a Landfill in a Non-Selective Manner,

Reclamation, on the other hand, is performed in accordance with the schedule of works related to the reclamation of a waste landfill, specified in the consent to the closure of a waste landfill or its separate part, in a way that protects the landfill from its harmful effects on surface and underground waters and the air, as well as integrating the landfill area waste with the surrounding environment and enabling observation of the impact of a landfill on the environment [4]. Reclamation, therefore, is a continuous process, often lasting more than a decade. Developing a landfill reclamation project is not an easy task. This is because it determines the minimization of the potentially negative impact on the environment and the extent to which it is possible to restore the degraded areas to their natural or utility values [7].

In 2012, at the request of the National Fund for Environmental Protection and Water Management, the document entitled Wytyczne dotyczące zamykania i rekultywacji składowisk odpadów komunalnych (Eng.: Guidelines for closing and reclaiming municipal landfills) was created according to which there are five stages in the process of reclamation of post-waste landfills: preparation of reclamation, technical reclamation, biological and detailed reclamation, 
restoration of the economic utility of the land and monitoring the effects of reclamation [3].

In the case of reclamation of the landfill in Grudziądz, no specific guidelines were available, while the reclamation plan was commissioned to specialists and scientists dealing with environmental protection issues on a daily basis. In this way, the reclamation plan was created as part of the document discussed in this article entitled Rekultywacja i ukształtowanie terenu wysypiska z możliwością jego eksploatacji do końca 1996 r. (included in its section entitled Projekt Techniczny Rekultywacji i Ukształtowania Terenu Wysypiska z możliwością jego eksploatacji do końca 1996 r. (Eng. Technical Project for the Reclamation and Formation of the Landfill Area with the possibility of its exploitation by the end of 1996), which provided for the possibility of energetic use of biogas generated in the landfill. The main purpose of the study was to enable the use of the landfill at Rataja Street until the construction of a new one in Zakurzewo is accomplished, while carrying out reclamation works at the same time.

It should be noted that the adopted formula for reclamation of the landfill in Grudziądz at Rataja Street followed, in a sense, a unique path - not only because of the lack of top-down guidelines, but also because of the solutions applied.

The aim of the study is to present a case study of a rehabilitated landfill site located in Grudziądz (Kuyavian-Pomeranian Voivodeship), in which the reclamation process, the technologies used and the results of control tests of the waste heap are presented.

\section{DESCRIPTION OF THE RESEARCH OBJECT}

The studied landfill was located at Rataja Street in the southern part of Grudziądz (currently Kujawsko-Pomorskie Province, and Bydgoszcz Province at the time the landfill was established), near the residential district of Rządz. The landfill site was located a short distance west of the road connecting Grudziądz with Torun and about $800 \mathrm{~m}$ south of the Rzadz district. From the south, the landfill area was limited by Rataja Street. To the west and north of the landfill, there were wastelands with single residential and farm buildings, which can be found in the greatest concentration in the immediate vicinity of the shore of Rządz [1], and now also (in 2020) - the newly built "Dębowe Wzgórze" housing estate. 


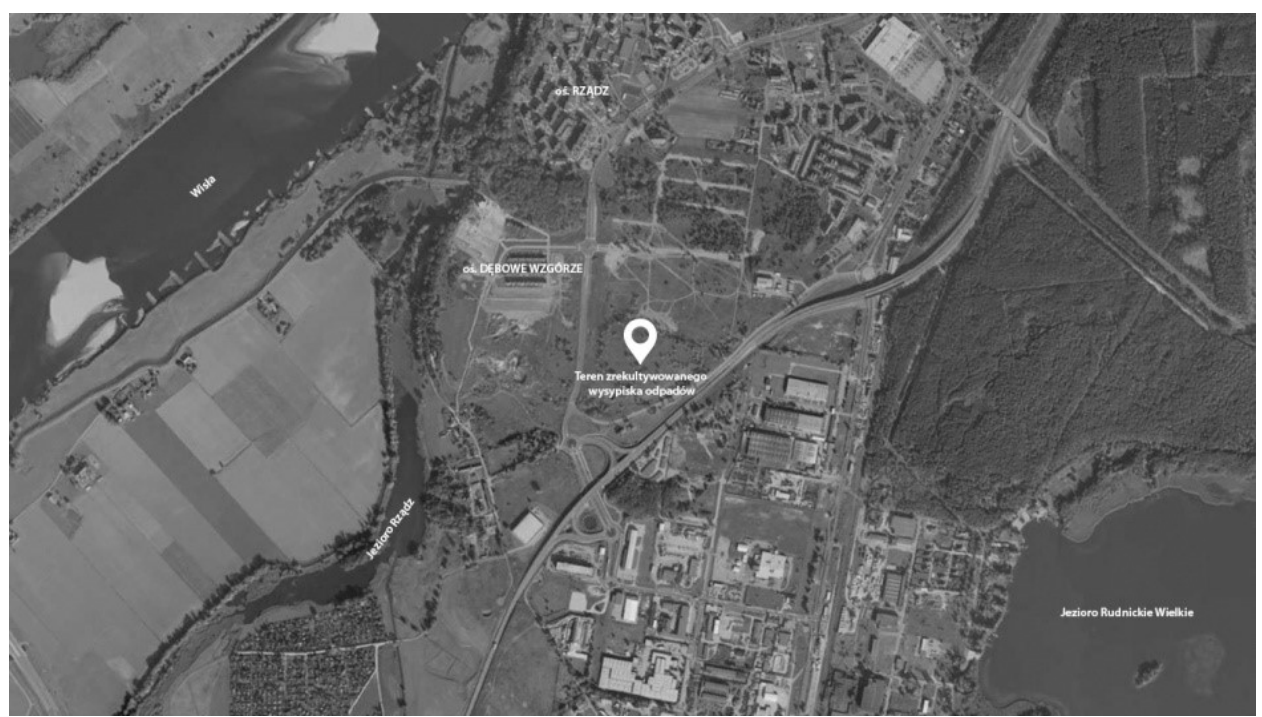

Fig. 1. Satellite view with the location of the landfill marked. Own elaboration based on [5]

The post-mining trough left after a former gravel mine in which the process of obtaining minerals was completed was used for the landfill. The decision to terminate the activity was made when the best-quality aggregates had already been extracted - and in the central part - after reaching the groundwater level [8]. The landfill - operating since 1973 - was used to store municipal waste from the town and commune of Grudziądz, as well as municipal waste from industrial plants and service sectors. Raw waste was stored directly on the ground, with no protection of the aquifer (located in the central part) and the ground. Until 1990, the landfill did not have any operational nor ecological safeguards in the form of a fence and an isolation green zone. The lack of the fence or the entrance gate with constant supervision enabled smuggling waste other than municipal waste to the landfill in the years 1973-1990 [8]. The landfill was operated in the traditional manner. The waste was dropped from trucks and spread with a caterpillar bulldozer, which simultaneously compacted it with its caterpillars [8]. Mineral soil was used for intermediate layers and waste was disinfected with lime. The degree of compacting the waste with this technique was not higher than 3 , which gives the bulk weight of the waste deposited immediately after compaction from 0.58 to $0.62 \mathrm{t} / \mathrm{m}^{3}$. During the operation period approximately 750,000 $\mathrm{m}$ were deposited in the landfill3 (450,000 tons) of waste with a bulk density of about $0.6 \mathrm{t} / \mathrm{m}^{3}$ which gives the annual capacity of about $30,000 \mathrm{~m}^{3} /$ year $(18,000$ tons/year) $[1,8]$. In 1994, the technological and operational data of the landfill were as follows: - landfill area - $6.29 \mathrm{ha}$,

- the area of the body of waste mixed at the ground level - 4.96 ha, 
- age of the landfill - 21 years,

- geometric volume of the landfill measured to the existing level - $630,000 \mathrm{~m}^{3}$.

\section{DESCRIPTION OF THE DESIGNED TECHNOLOGY USED TO PERFORM RECULTIVATION WITH ENERGY USE OF BIOGAS}

Due to the extremely unfavourable location, the lack of ecological protection and the depletion of the operational capacity, the facility was to be operated until the end of 1996 the latest, and then it was to undergo the reclamation process [8]. In 1994 the emission of landfill gases into the atmosphere was reduced by installing degassing wells, and thus the active degassing of the landfill with the energetic use of biogas was started [1]. The landfill, however, was still a source of groundwater contamination due to the lack of protection at its bottom. The effluents getting into the groundwater contained mineral compounds (mainly chlorides, sulphates and nitrogen compounds), organic compounds and microorganisms (including pathogenic ones) [1].

\subsection{The planned reclamation construction process - surface}

The method of carrying out reclamation depends on the final destination of the land after its clearing. In the case of the landfill in Grudziądz, due to its location within the town limits and the progressive expansion of the Rządz housing estate towards the landfill, a two-stage reclamation [8] was undertaken (in preparation: Rekultywacja i ukształtowanie terenu wysypiska z możliwością jego eksploatacji do końca 1996 r. [Eng.: Reclamation and landscaping of the landfill with the possibility of its use by the end of 1996].

Stage I was to be carried out in the 1995-1996 period. At that time, it was assumed that reclamation and investment works were carried out, including the final shape of the landfill body and the construction of facilities within the field of environmental protection, such as band ditches with a collective discharge channel.

It was suggested that the protective layer should be made as follows: after the last layer of waste has been laid and compacted, the supporting layer was to be placed directly on the waste, which was also to be a levelling and insulating layer. The supporting layer was to be about $10 \mathrm{~cm}$ thick and made of fine sands. Then, the suggestion was made to place a $20 \mathrm{~cm}$ thick semi-permeable layer of smoke dust, the aim of which was to protect the landfill from excessive rainwater inflow to the deposited waste. Still other suggested layer was a $15 \mathrm{~cm}$-thick drainage layer with a filtration coefficient selected in such a way that it could absorb most of the rainwater from the landfill surface and discharge it into the band ditches surrounding the dump [8]. 
At the same time, it was also necessary to continue degassing the landfill by means of the biogas intake installation and processing it into electricity. It was also suggested to simultaneously carry out preliminary reclamation, involving sowing the entire area with a mixture of grasses and fabaceae plants [8]. Planting could only be started when the temperature of the substrate decreased to the maximum of $25^{\circ} \mathrm{C}$. The composition of the suggestd mixture of grasses, fabaceae and legumes was as follows: Agrostis Vulgaris $-20 \%$, Festuca capillata $-20 \%$, Trifolium hybridum $-20 \%$, Trifolium repens $-20 \%$, Lipinus lutens $-10 \%$, Medicago lupulina - $10 \%$.

Stage II was to be accomplished in the 1997-2000 period. It was suggested at this stage to plant the area with low vegetation, and then with trees.

In the study entitled: Rekultywacja i ukształtowanie terenu... it was assumed that the operating period of the biogas installation will be 20-25 years. Based on these assumptions, the year 2020 was defined as the end of the reclamation process with the possibility of designating the facility for development.

\subsection{The applied technology of energy use of biogas}

As part of the reclamation work, landfill degassing installation was made, consisting of 17 wells collecting the generated biogas and aggregate collectors made of PVC pipes with a diameter of $110 \mathrm{~mm}$, connected to the MP90-T fan whose task was to suck in biogas from the well and transport it to the Small Biogas Power Plant (SBPP) building [1]. The SBPP used the captured biogas as a fuel to drive the internal combustion engine combined with an asynchronous generator with a capacity of $160 \mathrm{kVh}$. The energy generated in this way was fed into the national electricity grid [8]. Neither the internal combustion engine nor the generator were devices prepared specifically for the purpose of biogas processing. A properly adapted internal combustion engine from the decommissioned locomotive was used, with a factory-installed generator. The SBPP operated from 1994 to 2003. The amount of electricity produced at that time is presented in Figure 2. The highest production was recorded in the period from 1998 to 2000, when, for example, in 1999, 977.3 MWh of energy was obtained. Since 2002, there was a significant decrease in electricity produced. In 2002 , only $43 \%$ of energy sales were achieved in comparison with 2001. The decrease in electricity production was caused by numerous failures of the SBPP: in 2001 there were two failures (the months of May and December without energy production), in 2002 the months of February, March, August, November and December were without energy production. In 2003, at the turn of January and February, there was a failure, after which the gas use and electricity production were not resumed [1]. The failures were caused by the lack of proper maintenance, incl. topping up oil regularly. The engine seized up. 


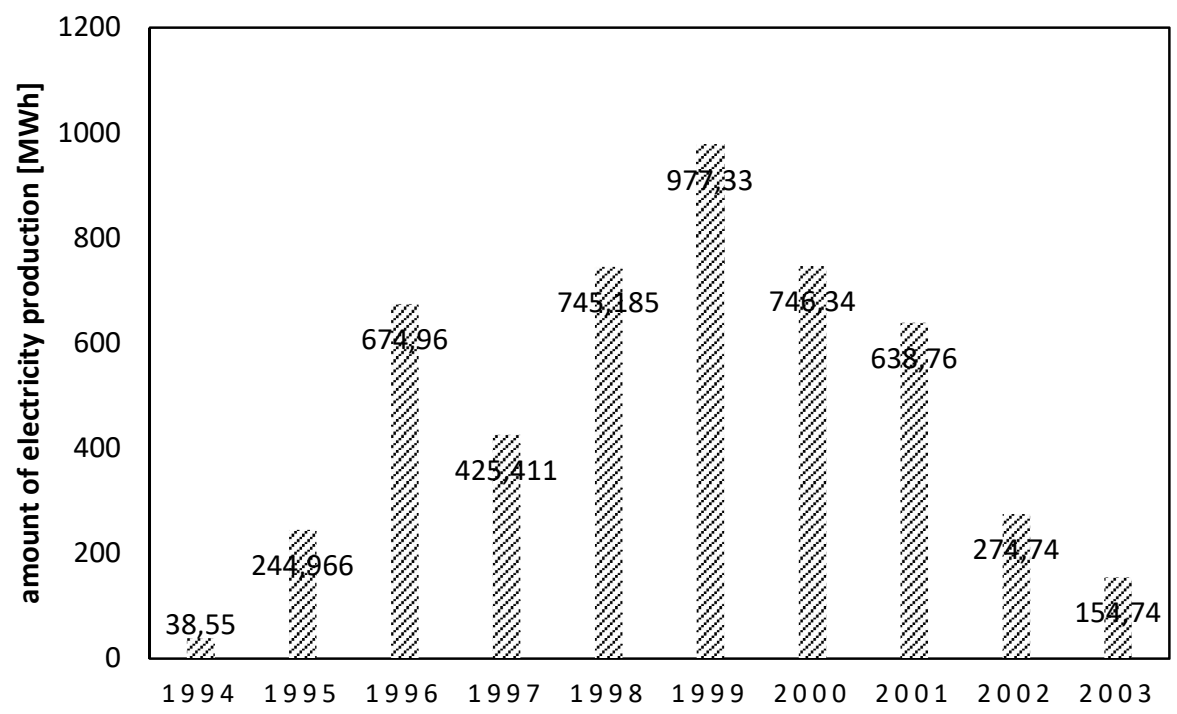

Fig. 2. The amount of electricity produced from biogas in the landfill in Grudziądz during the operation of the SBPP [1]

\section{CONDUCTING CONTROL CHECKS ON THE STATE OF THE RECLAMATION PROCESS IN 2007}

In 2007, due to the takeover of the land by the new owner - Okręgowe Przedsiębiorstwo Energetyki Cieplnej in Grudziądz Sp. z o.o. (OPEC Grudziądz), on March 12, 2007 an agreement was concluded between the University of Warmia and Mazury in Olsztyn and OPEC Grudziądz for the performance of the research project entitled Badania potencjału produkcji biogazu na zrekultywowanym terenie byłego wysypiska odpadów przy ulicy Rataja w Grudziądzu [1] (Eng.: Research on the potential of biogas production in the reclaimed area of the former landfill at Rataja Street in Grudziądz).

\subsection{Landfill surface inspection results}

The site visits of the landfill were carried out in the period from March 15 to May 31,2007 . They revealed that: “... the reclamation layer is in good condition, no intentional devastation or removal of side slopes was detected. Occasional cases of waste protruding from under the reclamation layer in the central part of the heap of the landfill were discovered (possibly the effect of intentional depositing of waste by the local population after the closure of the landfill). The entire surface of the heap is covered with vegetation. Tree stands are found only in the central part of the waste heap. Individually, mainly on the side slopes there are small trees 
and shrubs of species such as pine and willow, probably as a result of natural plant succession" [1].

The inspection of the performance of works related to the discharge of rainwater was concluded as follows: "In order to collect rainwater runoff on the surface of the reclamation layer and the filtration layer, band ditches were designed and performed. They were located in an encircling fashion, $1 \mathrm{~m}$ distance from the foot of the waste heap. Two ditches R1 and R2 were made, the lengths and slopes of which are L-640 and 314m, and - 3 and 9\%, respectively. The ditches discharge rainwater to the S1 collecting well located nearby the administration and social building, connected by means of the collecting canal to the rain collector running along Rataja Street. The bottom of the band ditches is made of concrete and protected with a $0.4 \mathrm{~mm}$ thick PVC foil, its slopes are reinforced with pavement tiles. [...] the site inspections showed that both ditches are in good condition and not devastated "[1].

\subsection{Groundwater monitoring within the landfill zone}

The landfill has been equipped with a network of piezometers to monitor groundwater. The network was created in 1997 for the purposes of creating the above-mentioned study on the obligations arising from the takeover of the biogas power plant by OPEC Grudziądz (Badania potencjatu produkcji biogazu ...). The groundwater in the subsurface quaternary aquifer was monitored. The geological work carried out showed that "in the area of the landfill there is a quaternary aquifer with water table elevations from 23.85 to $17.95 \mathrm{~m}$ above sea level The free water table is inclined towards the west with a $\mathrm{i}=0.0065$ slope. The filtration coefficient in the aeration and saturation zone is varied and is within $9.94 \times 10^{-6}$ $2.82 \times 10^{-3} \mathrm{~m} / \mathrm{s}$ range. It was found that due to the lack of insulation of poorly permeable formations above the aquifer, the water of the first level was exposed to direct contamination with compounds migrating with the leachate deeper through the aeration zone. The arrangement of piezometers was selected so that at least one of them would capture waters flowing under the landfill area "[1]. It was the so-called reference piezometer that characterized the inflowing clean waters. The remaining piezometers captured the water flowing from under the landfill [1]. It should also be remembered that "due to the lack of sealing of the bottom of the landfill and side slopes, and the lack of drainage capturing the leachate, there is no management of leachate within the landfill. All the water that seeps through the waste dump is leachate migrating into the aquifer" [1].

\subsection{Biogas management}

Before the start of the degassing of the landfill, in 1993 analyses of the generated biogas were performed both in static and dynamic conditions during biogas 
pumping. The results of these analyses are presented in Table 1. The same procedure was repeated during the 1997 audit work. The results of the conducted research indicated that the biogas content was characterized by a relatively low methane content, which did not exceed $30 \%$ of the volume. The $\mathrm{CH}_{4}$ to $\mathrm{CO}_{2}$ ratio was at the level of 1, indicating high intensity of processes taking place in the heap, with the processes of hydrolysis and methanogenesis in balance. An interesting fact was the high hydrogen content, which in some cases exceeded $10 \%$ of the volume. Hydrogen in landfill gas occurs only in the initial phase of landfill operation i.e. in the acetogenesis with a simultaneous high $\mathrm{CO}_{2}$ content. In further stages, the share of these gases is reduced, in favour of methane, as both hydrogen and carbon dioxide are used as substrates in the process of methanogenesis. Hydrogen should not be present in biogas from a landfill with developed methanogenesis, and $\mathrm{CO}_{2}$ concentration should be lower than the methane concentration [1]. In the case of the landfill in Grudziądz, 20 years after the landfill was established, the biochemical changes in the waste dump were not in the acetogenesis phase, but in the stable methanogenesis phase. It cannot be ruled out that the biogas tests carried out in 1993 and 1997 were burdened with an analytical error, and the specific calorific value of biogas is inconsistent with the theoretical values [1].

Table 1. Parameters of biogas from the landfill in Grudziądz determined in 1993 and $1997[1]$

\begin{tabular}{|c|c|c|c|c|}
\hline Conditions for biogas analyses & \multicolumn{2}{|c|}{ Static } & \multicolumn{2}{c|}{ Dynamic } \\
\hline Year of research & 1993 & 1997 & 1993 & 1997 \\
\hline $\mathrm{CH}_{4}$ & 28.1 & 25.2 & 28.6 & 25.9 \\
\hline $\mathrm{CO}_{2}$ & 30.5 & 25.3 & 25.2 & 25.5 \\
\hline $\mathrm{N}_{2}$ & 24.5 & 35.4 & 33.5 & 37.3 \\
\hline $\mathrm{O}_{2}$ & 1.6 & 1.5 & 0.9 & 2.3 \\
\hline $\mathrm{H}_{2}$ & 12.7 & 11.0 & 11.9 & 9.0 \\
\hline Calorific value $\left[\mathrm{kcal} / \mathrm{m}^{3}\right]$ & 3070.2 & 2730.8 & 3084.5 & 2724.0 \\
\hline Calorific value $\mathrm{kWh} / \mathrm{m}^{3}$ & 3.6 & 3.2 & 3.6 & 3.2 \\
\hline Theoretical calorific value $\mathrm{kWh} / \mathrm{m}^{3}$ & 3.2 & 2.8 & 3.2 & 2.8 \\
\hline $\mathrm{CH}_{4} / \mathrm{CO}_{2}$ & 0.9 & 1.0 & 1.1 & 1.0 \\
\hline
\end{tabular}

\subsection{Characteristics of the deposited waste}

As part of the work related to the preparation of the study by UWM in Olsztyn Badania potencjału produkcji biogazu... a number of analyses were carried out, characterizing the waste inside - involving, among others, humidity, volume 
weight, smell, structure were determined, the BIO fraction was characterized in terms of its suitability for further changes in the fermentation process.

\section{Humidity}

Waste moisture content was determined within 24 hours from sampling. It ranged from 12.5 to 31.4 weight $\%$, The average humidity was 23.4 weight $\%$. According to the document: "It was found that the humidity of the waste was much lower compared to the humidity expected of the waste intended for fermentation, i.e. in the range of $60-70 \%$ by weight. [...]. This may indicate unfavourable conditions in the heap for biogas production and harvesting. The analysis of waste moisture content shows that water in the total mass of waste in the heap is about 100,000 $\mathrm{Mg}$. Calculations of the amount of leachate water generated in the Grudziądz landfill indicate that approximately $2,500 \mathrm{Mg}$ of water infiltrates the waste annually, which is only $2.5 \%$ of the water mass already contained in the waste. Thus, precipitation is not a significant source of water increasing the moisture content of the waste" [1]

Volumetric weight

The volumetric weight of the waste was determined on the day of sampling from the wells. It was pointed out that: "The volumetric weight ranged from 0.557 to $1.408 \mathrm{Mg} / \mathrm{m}^{3}$. The average volumetric weight was $0.975 \mathrm{Mg} / \mathrm{m}^{3}$. Its value depended on the depth from which the waste samples were collected. The samples taken from the bottom layers were characterized by the highest volumetric weight, while the samples taken from the near-surface layers were characterized by the lowest one. Such a dependence results from the compaction of waste deposited in former years with waste deposited in latter periods. The relatively high bulk density also results from the settling processes taking place in the heap, leading to the grinding of larger sized waste as a result of pressure and compression forces"[1].

\section{Smell of waste}

The purpose of determining the smell of waste was to identify possible nuisance to the nearby surroundings. It was noted that: "The smell of most of the extracted samples was slightly putrefied (characteristic of fermented municipal waste) [...] the smell should not be a great nuisance for the inhabitants of the adjacent Grudziądz districts and employees. No smells of chemical nature were detected that would indicate the deposition of potentially hazardous waste due to the presence of volatile, toxic organic compounds in the waste"[1]

\section{Structure of waste}

In order to study the structure of waste beneath the surface of the landfill heap, 7 holes were made and samples were collected at different depths. The results are 
presented in Table 2. It was shown that most of the samples were loose, and only in the waste collected from three holes the material was smeared. This could indicate a capillary leakage from groundwater, the mirror of which was in contact with the deposited waste in the area of these three holes [1].

The fractional and morphological analysis of the samples showed that plastics had the largest share in the deposited waste, $16.3 \%$ by weight and textiles $16.1 \%$ by weight. The remaining materials, such as glass or metals together, accounted for $3 \%$ by weight. The content of hazardous waste (bacteria, medical waste, deodorants) in the deposited waste was low $-0.14 \%$ by weight. Mineral materials, debris, ceramics, stone waste constitute about 9 weight $\%$ of the waste. The largest share in the deposited waste was the BIO fraction (the total content of the fractions below $10 \mathrm{~mm}$ ) of paper and other organic waste exceeded $55 \%$ by weight. The document emphasizes that: "Fractional analysis has shown that the largest share in waste is characterized by fine fractions below $40 \mathrm{~mm}$, the total share of which is nearly $70 \%$ by weight." [1]. This indicates large fragmentation of the waste deposited in the landfill, which is also confirmed by the high bulk density. The percentage share of selected morphological groups and fractions is presented in Table 2 [1].

Table 2. Percentage share of selected morphological groups and waste fractions [\% by weight] from the landfill heap in Grudziądz [1].

\begin{tabular}{|c|c|c|c|c|c|c|c|c|c|}
\hline & \multicolumn{9}{|c|}{ Morphological group of waste } \\
\hline Waste fraction & 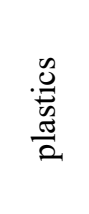 & 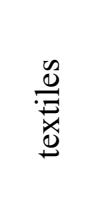 & $\frac{w}{\tilde{\sigma}}$ & $\begin{array}{l}\frac{n}{\pi} \\
\frac{\tilde{E}}{\Xi}\end{array}$ & 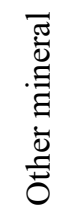 & 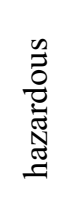 & $\begin{array}{l}\bar{\Phi} \\
\text { :्ञ } \\
\text { : }\end{array}$ & 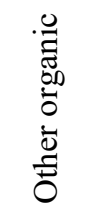 & $\frac{\Xi}{\Xi}$ \\
\hline$<10 \mathrm{~mm}$ & 0.00 & 0.00 & 0.00 & 0.00 & 0.00 & 0.00 & 0.00 & 24.33 & 24.33 \\
\hline $10-40 \mathrm{~mm}$ & 4.46 & 1.67 & 1.39 & 0.37 & 8.02 & 0.04 & 0.62 & 28.23 & 44.8 \\
\hline $40-120 \mathrm{~mm}$ & 7.51 & 5.53 & 0.24 & 0.66 & 0.73 & 0.10 & 0.24 & 1.98 & 17.00 \\
\hline$>120 \mathrm{~mm}$ & 4.43 & 8.89 & 0.00 & 0.45 & 0.00 & 0.00 & 0.00 & 0.19 & 13.87 \\
\hline Total sum & 16.31 & 16.09 & 1.64 & 1.48 & 8.75 & 0.14 & 0.86 & 54.73 & 100.00 \\
\hline
\end{tabular}

\section{SUMMARY}

This example shows the history of a landfill whose operation time was 21 years, while the estimated reclamation process took 23 years. In the course of the landfill operation - that is, from 1973 to 1997 - Poland underwent a lot of changes, including in the way of thinking about waste management. From the use of the hollow of the area created during the excavation of gravel, to securing and backfilling the heap and the recovery of biogas for energy purposes in 1994, the 
deposited waste became recyclable material in part. The issue of reclamation was dealt with by preparing plans for its implementation based on technical construction projects. As a result of these activities, in 2020 the area of the former landfill in Grudziądz became a place for re-development.

Thus, the solutions applied in Grudziądz are a part of an important, albeit still used scarcely, tendency of operating methods within the rehabilitation processes. Therefore, the analysed case study can be considered one of the important methods of reclamation of a municipal landfill.

The presented example of landfill reclamation in Grudziądz also proves that it is not always necessary to use costly, modern solutions with a high degree of automation to effectively rehabilitate a landfill and, in addition, to use biogas for energy purposes. Sometimes simple constructions (like an engine from a disused diesel locomotive) can be a perfect, effective and at the same time inexpensive solution.

\section{REFERENCES}

1. Białowiec, A, Agopsowicz, M, Kopik, M and Kasiński, S 2007. Badania potencjału produkcji biogazu na zrekultywowanym terenie byłego wysypiska odpadów przy ulicy Rataja w Grudziądzu. UWM, Olsztyn, 3-34.

2. Journal of Laws, Chapter 1 - Landfilling - Waste. [accessed 18-10-2020] Obtained from <https://sip.lex.pl/akty-prawne/dzu-dziennik-ustaw/odpady$17940659 / \mathrm{dz}-8$-roz-1>

3. Manczarski, P and Lewicki, R Warszawa 2012. Wytyczne dotyczące zamykania i rekultywacji składowisk odpadów komunalnych.

4. Regulation of the Minister of the Environment dated 30 April 2013 on the matter of landfill sites (Journal of Laws 2013, item 523 as amended).

5. Spatial Information Infrastructure Geoportal. [accessed 16-10-2020] $<$ https://mapy.geoportal.gov.pl/imap/Imgp_2.html?gpmap=gp0>

6. Wiater, J 2011. Wpływ składowisk odpadów komunalnych na jakość wód podziemnych i właściwości gleb. Inżynieria Ekologiczna 26, 134.

7. Więcławska J. 2015. Spektakularne metamorfozy składowisk odpadów. 1 4. [accessed 28-10-2020]. Obtained from $<$ https://portalkomunalny.pl/spektakularne-metamorfozy-skladowisk odpadow-316374/>

8. Wołoszyn, T, Ossowski, Z, Tolarczyk, R and Wysocki, M 1995. Rekultywacja i ukształtowanie terenu wysypiska $\mathrm{z}$ możliwością jego eksploatacji do końca 1996 r. Projekt techniczny + przedmiar. 